\title{
Cross-cultural adaptation, face validity and reliability of the Model of Human Occupation Screening Tool to Brazilian Portuguese ${ }^{1}$
}

\author{
Daniel Marinho Cezar da Cruz ${ }^{a}$ (D), Sue Parkinson ${ }^{b}$ (i), Daniela da Silva Rodrigues ${ }^{c}$ (D), \\ Débora Couto de Melo Carrijo ${ }^{a}$ (D), Jacqueline Denubila Costa ${ }^{a}$ (D), Emerson Fachin-Martins ${ }^{c}$ (D), \\ Luzia Iara Pfeifer ${ }^{d}$ (D)
}

\author{
aUniversidade Federal de São Carlos - UFSCar, São Carlos, SP, Brasil. \\ ${ }^{\mathrm{b}}$ Freelance MOHO trainer, Chesterfield, United Kingdom. \\ 'Universidade de Brasília - UnB, Brasília, DF, Brasil. \\ dUniversidade de São Paulo - USP, Ribeirão Preto, SP, Brasil.
}

\begin{abstract}
Introduction: The Model of Human Occupation Screening Tool (MOHOST) was developed in the UK and measures the occupational participation. Until its translation, there were no standardised instruments in Brazil of a similar nature. Objectives: To describe the translation and cross-cultural adaptation process of the MOHOST for Brazil, its face validity and test-retest reliability among occupational therapists. Method: A translation agreement was established allowing the assessment to be translated and honed after a back translation. An expert committee was formed of ten occupational therapists to test face validity of the instrument with 50 occupational therapists. Statistical analysis was employed to investigate whether the occupational therapists' understanding of the MOHOST was linked to their length of clinical experience. The test-retest reliability was examined among a sample of eight adults with physical disabilities. Results: The cross-cultural adaptation of the Brazilian MOHOST has been completed. A significant correlation $(\mathrm{p}=0.04$ ) was found between years of professional experience and greater understanding of the MOHOST items. The MOHOST presented very high reliability in the test-retest $(r>0.900)$. Conclusion: A Brazilian translation of the MOHOST has face validation and test-retest reliability. Future studies addressing this instrument's psychometric properties of validity and inter-rater reliability are recommended.
\end{abstract}

Keywords: Occupational Therapy, Validation Studies, Rehabilitation.

\section{Adaptaçáo transcultural, validade de face e confiabilidade do Instrumento de Identificaçáo da Participaçáo Ocupacional do Modelo de Ocupaçáo Humana para o português do Brasil}

Resumo: Introdução: O Instrumento de Identificação da Participação Ocupacional do Modelo de Ocupação Humana (MOHOST Brasil) foi desenvolvido no Reino Unido e mensura a participação ocupacional. Até a sua presente tradução, para o Brasil, não haviam instrumentos padronizados e que mensurassem o mesmo constructo. Objetivos: Descrever o processo de tradução e adaptação cultural do MOHOST para o Brasil, examinar a sua validade de face e confiabilidade no teste-reteste por terapeutas ocupacionais. Método: Inicialmente foi estabelecido um contato para a autorização da tradução e, posteriormente, seguidas as etapas de tradução, retrotradução, comitê de especialistas, validade de face e teste-reteste. O comitê de especialistas foi composto por dez terapeutas ocupacionais. A validade de face contou com a participação de 50 terapeutas ocupacionais. A análise estatística foi empregada para investigar se o entendimento do MOHOST pelos terapeutas ocupacionais estava vinculado à sua duração da

Corresponding author: Daniel Marinho Cezar da Cruz, Departamento de Terapia Ocupacional, Universidade Federal de São Carlos, Rodovia Washington Luis, Km 235, CP 676, CEP 13565-905, São Carlos, SP, Brasil, e-mail: danielcruz@ufscar.br

Received on July 10, 2019; Accepted on Sept. 23, 2019.

Este é um artigo publicado em acesso aberto (Open Access) sob a licença Creative Commons Attribution, que permite uso, distribuição e reprodução em qualquer meio, sem restrições desde que o trabalho original seja corretamente citado. 
experiência clínica. A confiabilidade teste-reteste foi examinada em uma amostra de oito adultos com deficiência física, em um intervalo de uma semana. Resultados: A adaptação transcultural do MOHOST (Brasil) foi concluída. Foi encontrada uma correlação significativa $(p=0,04)$ entre anos de experiência profissional e maior entendimento dos itens do MOHOST. O MOHOST apresentou confiabilidade muito alta no teste-reteste ( $r>0,900)$. Conclusão: A versão brasileira apresenta validação de face e confiabilidade no teste-reteste. Estudos futuros abordando as propriedades psicométricas de validade convergente e confiabilidade entre avaliadores são recomendados.

Palavras-chave: Terapia Ocupacional, Estudos de Validação, Reabilitação.

\section{Introduction}

Occupational therapists are striving to refocus their practice on occupational participation that goes beyond addressing impairments (KRAMER et al., 2009). This endeavour is advanced by the application of theories that ground their practice and the use standardized measures (MACIVER et al., 2016). In practice, however, the quest to identify reliable assessments and measures continues to present dilemmas for therapists (HAWES; HOULDER, 2010).

The use of specific Occupational Therapy instruments is still incipient in Brazil (CRUZ, 2018; CHAVES et al., 2010). Various nonspecific assessments are available for occupational therapists to use in their practice and research, but from an occupational perspective it is important to assess patients and implement interventions that favour engagement in meaningful occupations, which makes the selection of specific occupational therapy assessments critical (NOTOH et al., 2013).

The theoretical framework of the Model of Human Occupation (MOHO) and its associated assessments have been researched over 4 decades, and there is evidence that $\mathrm{MOHO}$ is the model most frequently used worldwide (CRUZ, 2018; TAYLOR, 2017; LEE et al., 2012). Its use and development in South American countries - including Argentina, Chile and Venezuela - has been well-documented by De las Heras de Pablo, Wei-Fan and Kielhofner (2017). Meanwhile, in the UK, the Model of Human Occupation Screening Tool (MOHOST) is considered to be the most widely used assessment in mental health occupational therapy services (MORLEY; BIRKEN, 2014) and has been translated into 19 languages, - namely: Arabic, Danish, Dutch, Finnish, French, German, Icelandic, Japanese, Korean, Mandarin, Norwegian, Persian, Polish, Spanish, Swedish, Turkish, Portuguese (Portugal), and now Brazilian Portuguese (MACIVER et al., 2016; MODEL..., 2016).

Four essential elements are considered in the MOHO: volition, habituation, performance capacity, and environment (KIELHOFNER, 2008; KIELHOFNER et al., 2010; TAYLOR, 2017), and the (MOHOST) gives an overview of a person's occupational functioning in all these areas (PARKINSON et al., 2017). It can be used to assess the factors that influence the occupational participation of individuals with psychosocial or physical impairments (PARKINSON et al., 2017; FORSYTH et al., 2011), by determining whether individual and environmental factors facilitate, allow, restrict or inhibit a person's occupational participation in daily life (KRAMER et al., 2009).

A study conducted by Kramer et al. (2009) reports the consistent use of this measure by the occupational therapists of one hospital, and showed that the MOHOST is sensitive to identifying changes that take place between hospital admission and discharge. Moreover, it was found that occupational therapists with minimum training used the instrument consistently to measure changes in participation (KRAMER et al., 2009). Another study reports that occupational therapists in the United Kingdom considered the MOHOST to be an instrument that consistently facilitates evidence-based practice without compromising professional autonomy or patient-centred care (HAWES; HOULDER, 2010).

The objectives of the study described below were as follows:

1) To complete the translation and cross-cultural adaptation of the MOHOST version 2.0 (PARKINSON; FORSYTH; KIELHOFNER, 2006) to Brazilian Portuguese;

2) To examine the translation's face validity with Brazilian occupational therapists; and

3) To examine the test-retest reliability with a sample of adults with physical disabilities.

\section{Methods}

\subsection{Ethical aspects}

This study was submitted to and approved by the Institutional Review Board at a federal public university (CAAE opinion report: 68946717.7.0000.55040). All the participants (occupational therapists and individuals with disabilities) provided their consent by signing informed consent forms. 


\subsection{Study design}

The findings detailed in this article are from a methodological, cross-sectional, non-experimental study with quantitative analysis following a cross-cultural adaptation of the MOHOST. The translation was based on the two cross-cultural adaptation guidelines most frequently used: the Guidelines for the Process of Cross-Cultural Adaptation of Self-Report (BEATON et al., 2000) and the Principles of Good Practice for the Translation and Cultural Adaptation Process for Patient-Reported Outcomes (PRO) Measures (WILD et al., 2005). The study was developed in two public universities in the state of São Paulo, Brazil. Data were collected via email from occupational therapists, who composed the Expert Committee and from 50 occupational therapists affiliated to a university to obtain face validity.

\subsection{Procedures}

\subsubsection{Stage I: translation}

As suggested by Wild et al. (2005), the primary author of this study contacted the primary author of the original instrument in English asking for her permission to use it. The Model of Human Occupational Clearinghouse (based in the Occupational Therapy Department at the University of Illinois, Chicago, United States) was also contacted to establish a Copyright Translation Agreement and agree a plan for assessment dissemination of the instrument in Brazil. After approval, two independent translators (T1 and T2) initiated the translation of the MOHOST from its 'original' language (English) to the 'target' language (Brazilian Portuguese). T1 is an occupational therapist fluent in English, familiar with the concepts measured by the instrument, while T2 is a language professional who was unaware of the instruments concepts, as recommended by the guidelines (BEATON et al., 2000).

\subsubsection{Stage II: synthesis of the translations}

After completing the two translations, provided by the translator one (T1) and translator two (T2) met to review the level of agreement and synthesize their versions, creating a single final version of the assessment named as T12 (BEATON et al., 2000).

\subsubsection{Stage III: back translation}

The synthesis of the Brazilian versions (T12) was submitted to two professionals; translator one (BT1) and translator two (BT2), whose mother tongue is
English, who back translated the Brazilian version to English (BT1 and BT2). The translators, who are native to England, the United Kingdom, did not have contact with the instrument's original version. This stage was intended to verify whether the content of the translated version was compatible with the content of the MOHOST's original version (BEATON et al., 2000). Two of this study's authors analysed the back-translated versions, BT1 and BT2 and achieved a synthesis of the back-translated versions in a single final version of the assessment named as BT12.

Afterwards, the items of the original version in English that differed from the synthesis of the back-translated versions were discussed with the primary author of the original MOHOST instrument to clarify discrepancies and specify terms. As suggested by the literature, this procedure was intended to ensure that the translation is accurate and the most relevant characteristics of the original instrument are retained in the translated version (COSTER; MANCINI, 2015). Another table with four columns was created; the first column presented the items of the original instrument, followed by the two columns that presented the back translations, while the final column was intended for the authors' comments. From this process emerged the revised version, RT12.

\subsubsection{Stage IV: expert validation}

A committee was created to validate RT12, composed of a convenience sample of ten experts who met the following inclusion criteria: occupational therapists with degrees; working in rehabilitation services intended for adults; and/or with experience with cross-cultural adaptation research. In addition to these professionals, two of the study's authors participated, including the primary author, and the four translators of the Brazilian and English versions (BEATON et al., 2000).

A script was created for comparative analysis, that is, for the Expert Committee to check whether RT12 was compatible with the original version of the MOHOST. The original version was broken down into parts by counting the number of items and number of phrases; a total of 120 statements were found. A table with columns listing the 120 sentences of the MOHOST original version and the corresponding items in the Brazilian version was sent by e-mail for the experts to assess the instruments semantic, idiomatic, cultural and conceptual equivalences (BEATON et al., 2000; GUILLEMIN; BOMBARDIER; BEATON, 1993). 
Semantic equivalence refers to the correspondence of meanings of words, while idiomatic equivalence refers to the use of expressions that are common and equivalent in both countries. That is, the expressions in both languages portray situations that are compatible in meaning. Hence, semantic and idiomatic equivalences refer to the ability of transferring the meanings of concepts contained in the original instrument to the translated version. Cultural equivalence confirms that the translated version is equivalent in regard to the situations that are portrayed, while conceptual equivalence confirms the construct is coherent with what it is intended to measure (BEATON et al., 2000; GUILLEMIN; BOMBARDIER; BEATON, 1993).

\subsubsection{Stage V: confirmation of face validity}

Face validity requires that experts assess the acceptability of the instrument, seeking to establish cultural adequacy in terms of interpretation and historical accuracy, while achieving inter-rater reliability (ALEXANDRE; COLUCI, 2011). In addition to the expert committee reviewing RT12, a convenience sample of 50 occupational therapists was recruited from a higher education institution to verify how clear, relevant and acceptable the concepts were considered to be (GRAVETTER; FORZANO, 2012; HOLDEN, 2010; GUILLEMIN; BOMBARDIER; BEATON, 1993).

The inclusion criteria for the convenience sample were: being an occupational therapist with a degree; and having no prior contact with the instrument. They each completed a form addressing personal information as follows: age; college where degree was obtained and whether it was a Bachelor's, Master's or Doctorate degree); main field of professional practice; experience with $\mathrm{MOHO}$; and years working in occupational therapy.

The therapists analysed the 120 items in regard to clarity, rating them either as 'comprehensible' or 'incomprehensible'. A blank space was available for the participants to post qualitative comments regarding the items considered incomprehensible so that unclear items could be reviewed later. Data were organized in a table taking into account the comments provided regarding each of the instrument's items. Central tendency (mean, minimum and maximum) and dispersion (standard deviation) measures were adopted. Spearman's rank order correlation was used to verify whether years of experience, familiarity with the MOHO, and understanding of the MOHOST's items were correlated. SPSS version 20.0 was used and the level of significance was set at .05 .
The results were subjected to statistical analysis as follows. The median and lower and upper limits of two quantitative variables (Occupational Therapist's experience [OT's experience] and percentage of understanding [\% of understanding]) and one qualitative variable (previous knowledge of the $\mathrm{MOHO}$ ) were calculated considering a $95 \%$ Confidence Interval $(95 \% \mathrm{CI})$, while a percentage of the sample (\% of the sample) was distributed into two classes of answer (no or yes). The D'Agostino $\&$ Pearson normality test revealed a non-parametric distribution for all quantitative variables, and for this reason, Spearman's correlation test was applied.

The Correlation Coefficient (r) ranges from -1 up to 1 , where $r=0$ represents no correlation, while $r>0$ and $r<0$ represent perfect direct or inverse proportional correlation, respectively; $r>0.90$ was classified as very high correlation, $0.90<\mathrm{r} \leq 0.70$ as high correlation, $0.70<\mathrm{r} \leq 0.50$ as moderate correlation, $0.50<\mathrm{r} \leq 0.25$ as low correlation, and $\mathrm{r}<0.25$ as poor correlation.

\subsection{Test-retest reliability}

The study setting included one healthcare unit focused on the rehabilitation of individuals with physical disabilities in the South East of Brazil. The MOHOST was applied by eight occupational therapy undergraduate students under supervision of on professor. They were provided with training in the Model of Human Occupation by the primary author, and were given the MOHOST form containing written instructions. Eight clients with physical disabilities had their MOHOST completed twice; in an interval of a week as previous studies recommend (PAULISSO et al., 2019).

The magnitude of difference in the MOHOST ratings was analysed and plotted by the Bland-Altman method, with a confidence interval of $95 \%$, the limits of which correspond to the limits of agreement. The analysis was initially performed for the MOHOST total score and, afterwards, for the scores of each of the six factors assessed.

\section{Results}

\subsection{Stages I and II: translation and synthesis of translations}

A few divergences were found between translations T1 and T2 in regard to the semantic analysis of the words: "conversation"; "aware"; "appropriate"; "demands"; "distractible"; "decision-making"; "seeks reassurance"; "mobility in occupation"; "throughout occupation"; "evidence of fatigue"; "valued occupations"; "some groups support, but not 
others". The authors analysed the divergences and considered that the suggestions for these terms were more appropriate to be included in translation T12.

\subsection{Stage III: back translation'}

The back-translated version was compared to the MOHOST original version in English to check for the compatibility of items. The authors identified the following divergences: the title of the original instrument "Model of Human Occupation Screening Tool (UK English)" was back translated as "Tracking Tool for Model of Human Occupation (MOHO) Assessment Form (British English)"; "Summary of Ratings" as "Classification Summary"; and "Appraisal of ability" as "Evaluation of ability. The word "tracking" was removed from the title because it does not have the same meaning as "screening" and the MOHOST screens for occupational needs, defined as checking and detecting/identifying. Therefore, the word "identification" was adopted in the final decision process. "Classification Summary", which was back translated as "Summary of Results" was accepted. "Evaluation of ability" suggests an evaluation via thorough examination, so that the final decision was to replace it with "Judgement of ability".

\subsection{Stage IV: expert validation}

The therapists participating in this stage reported between seven and 30 years since graduation, five had a PhD degree, and nine had a Master's degree. In this stage, the committee compared the MOHOST original and the Brazilian versions to check for the semantic, idiomatic, cultural and conceptual equivalences of items.

Of the 10 experts, only two disagreed with regard to the items that had been translated into Portuguese. Table 1 presents the alternative suggestions made by

Table 1. Divergences between Experts 2 and 4 and final decision for the MOHOST Brazil.

\begin{tabular}{|c|c|c|c|c|}
\hline E* & MOHOST UK & MOHOST Brazil & $\mathrm{E}^{*}$ suggestions & $\begin{array}{l}\text { Final Decision of MOHOST } \\
\text { Brazil }\end{array}$ \\
\hline 2 & Stamina & Vigour & Energy & $\begin{array}{l}\text { Rejected (the term "energy" is } \\
\text { adopted in another item) }\end{array}$ \\
\hline 4 & Appraisal of Ability & Judgment of Ability & Assessment of ability & $\begin{array}{l}\text { Rejected because "judgment } \\
\text { of ability" was recommended } \\
\text { during the reconciliation of the } \\
\text { back-translated versions. }\end{array}$ \\
\hline
\end{tabular}

4 Accurate belief in Accurate belief in Accurate belief in the skill, accurate view of skill, accurate view of skill, accurate view of competence

Does not reflect on skills, fails to realistically estimate own abilities

Has some hope for success, adequate self-belief but has some doubts, may need encouraging

Sense of value and meaning

4 Mostly able to make choices, may need encouragement to set and work towards goals

4 Identifies with a variety of roles, has a sense of identity/ belonging that comes from roles competence

Does not reflect on skills, fails to realistically estimate own abilities

Has some hope for success, adequate self-belief but has some doubts, may need encouraging

Sense of value and meaning

Mostly able to make choices, may need encouragement to set and work towards goals

Identifies with a variety of roles, has a sense of identity/ belonging that comes competence

Does not reflect on skills, fails to realistically assess own abilities

Has some hope for success, adequate self-belief but has some doubts, will probably require encouraging Sense of value and purpose

Able to make choices most of the time and may need encouragement to set and work towards goals comes or accrues from roles
Suggestion accepted

\section{Suggestion accepted}

Rejected because it does not accurately reflect the original version

Rejected because it does not accurately reflect the original version

Suggestion accepted

Suggestion accepted 
these experts (number 2 and 4), as well as the final decision adopted by the study's authors.

\subsection{Stage VI: confirmation}

The preliminary Brazilian version of the MOHOST (RT12) was sent to 50 occupational therapists to check for comprehension of items (face validity). Figure 1 presents the results concerning years of professional experience, familiarity with the $\mathrm{MOHO}$, and correlation between professional experience and level of understanding of the MOHOST's items.

The box-plot presented in Figure 1A shows that most of the sample (more than 75\%) was composed of Occupational Therapists with two or more years of experience. Half of the therapists were not familiar with the MOHO (see Figure 1B) and among these individuals, those with more years of professional experience showed a greater understanding of the MOHOST's items. A significant correlation $(\mathrm{p}=0.0467)$ was found between more experienced participants and greater understanding ( $>98 \%)$ (see Figure 1C in which the area of the graph is arranged in quadrants defined by a level of understanding of $98 \%$ and eight years of professional experience). There were no occupational therapists with more than eight years of experience whose understanding of the MOHOST concepts was lower than 98\%. Meanwhile, two occupational therapists with less than eight years of experience presented with the lowest levels of understanding, albeit that they still comprehended $90 \%$ or more of the concepts.

Table 2 presents the percentage of understanding in decreasing order for each of the MOHOST's domains. Note that understanding reached almost $100 \%$ in all the domains, considering each domain contains 20 items.
A

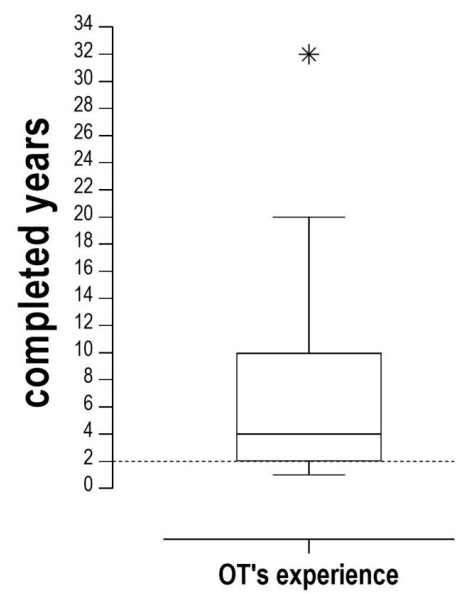

C
B

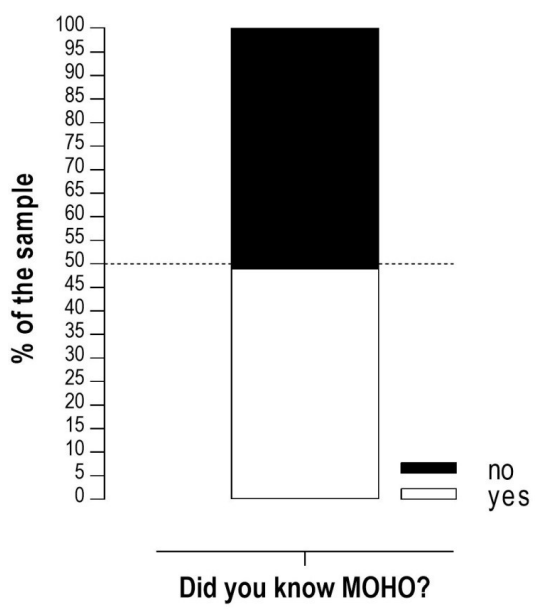

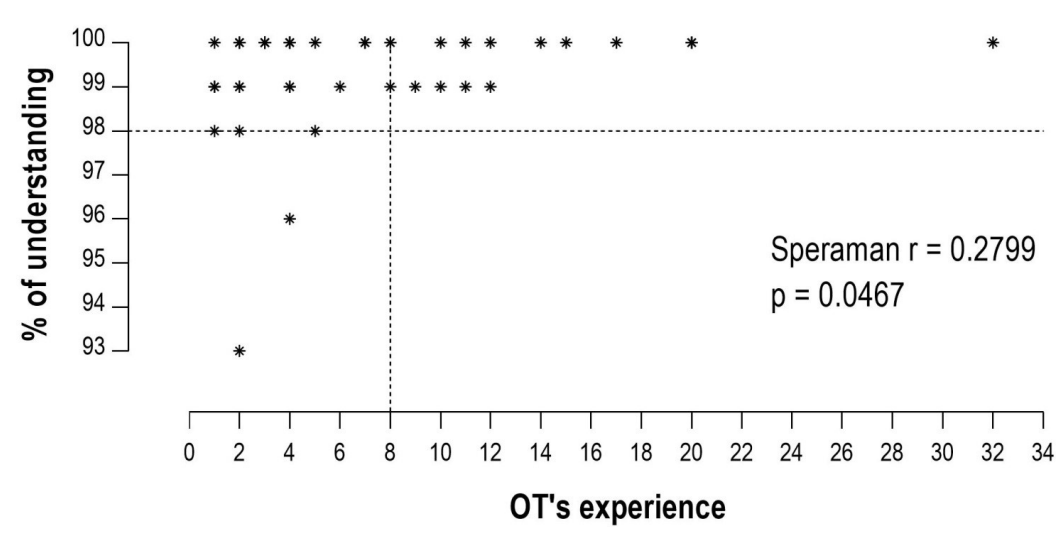

Figure 1. (A) Years of professional experience; (B) Familiarity with the MOHO, and correlation between professional experience; and $(\mathrm{C})$ Level of understanding of the MOHOST's items. 
Table 2. Descriptive data concerning the level of understanding of occupational therapists of the MOHOST's domains ( $\mathrm{n}=50)$.

\begin{tabular}{lcc}
\hline \multicolumn{1}{c}{ MOHOST domains } & \% of Understanding & $\begin{array}{c}\text { Understanding's hierarchical } \\
\text { order }\end{array}$ \\
\hline Motivation for occupation & $98.92 \%$ & 5 \\
Pattern of occupation & $99.51 \%$ & 3 \\
Communication \& interaction skills & $99.51 \%$ & 3 \\
Process skills & $99.31 \%$ & 4 \\
Motor skills & $99.71 \%$ & 1 \\
Environment & $99.61 \%$ & 2 \\
Maximum & 99.71 & - \\
$75 \%$ Percentile & 99.64 & - \\
Median & 99.51 & - \\
25\% Percentile & 99.21 & - \\
Minimum & 98.92 & - \\
Mean & 99.43 & - \\
Std. Deviation & 0.2822 & - \\
Std. Error of Mean & 0.1152 & - \\
Upper 95\% CI of mean & 99.72 & - \\
Lower 95\% CI of mean & 99.13 & - \\
Coefficient of variation & $0.28 \%$ & - \\
\hline
\end{tabular}

\subsection{Test-retest reliability}

The participants of the test-retest were eight clients (three were females and five males) who had their MOHOST completed twice. Six had Stroke and one Charcot Marie Tooth as diagnosis. The mean age was $53.14( \pm 19.39)$ years old.

Figure 2 presents the general data concerning the test-retest. The total score obtained on the MOHOST presented very high reliability $(r>0.900)$ for all the repeated measures in the retest. The differences between the measures are all within a 95\% confidence interval. In half of the observations (differences of four repeated measures), differences ranged from -2 to 4 points, with the repeated measures presenting the highest difference (other four measures) in the interval between 4 and 10 points. Note that $80 \%$ of the differences generated positive values when the retest measure was subtracted from the test measure (test-retest), showing that higher scores were recorded for the test than for the retest.

Figure 3 presents the test-retest for the MOHOST's six factors. When the same analysis was performed for the scores of each of the MOHOST's factors, differences were verified between a 95\% confidence interval with $\mathrm{LOA}<18.374$. All the analyses presented in Figure 3 show at least one repeated measure without difference in the retest (asterisks that touched the line with value equal to 0 in all the Bland-Altman plots) according to Figures $3 \mathrm{~A}-\mathrm{F}$. The largest range for LOA was found for the repeated measures in

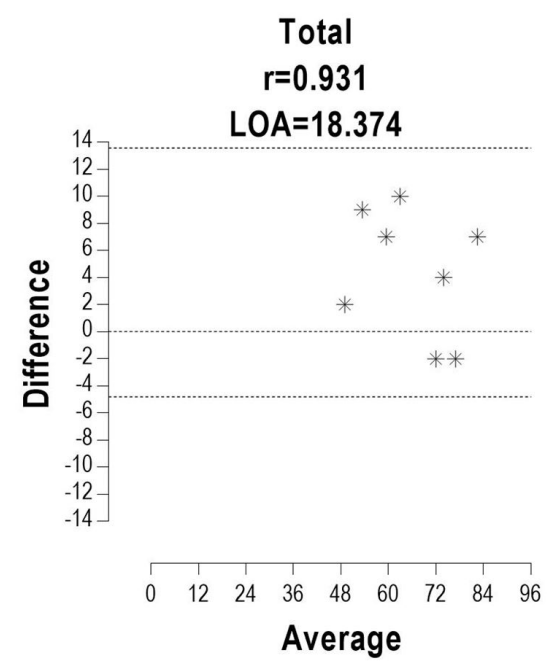

Figure 2. Bland-Altman plot of test/retest comparison between repeated total measures of the MOHOST for each participant $\left(^{*}\right)$. Upper and lower discontinuous traces show the bounds of a $95 \%$ range of the limit of agreement (LOA), as well as the zero value in between them. The LOA and the Pearson Coefficient ( $\mathrm{r}$ ) between measures obtained during test and retest were indicated in the top of the graph.

the factor "Motor Skills" (Figure 3E), while the lowest was obtained for the differences of repeated measures in the factor "Pattern of occupation" (Figure 3B). The range in the remaining factors was between 4 and 5 points. 

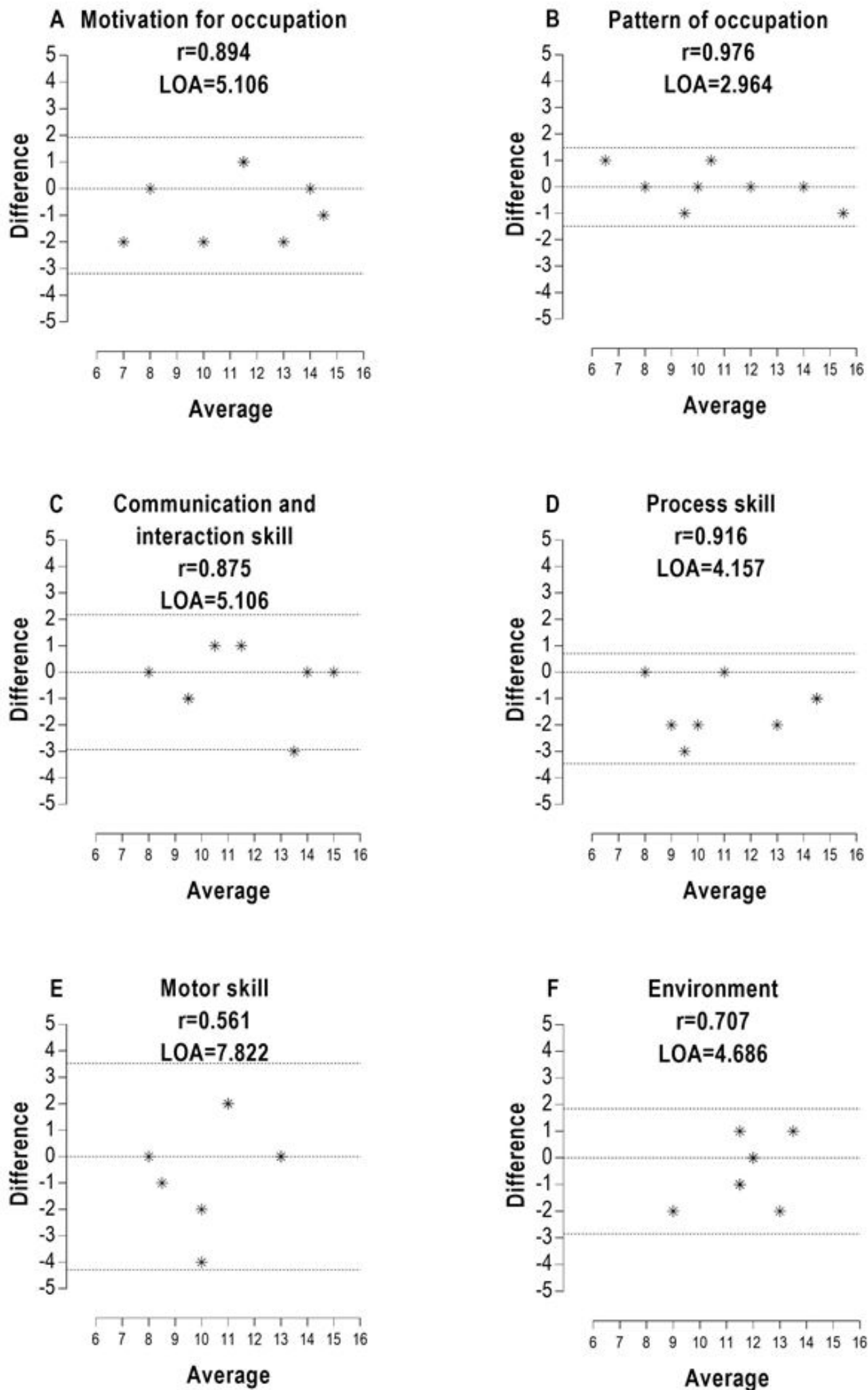

Average

Figure 3. Bland-Altman plot of test/retest comparison between repeated measures for factors of the MOHOST from A up to F for each participant $(*)$. Upper and lower discontinuous traces show the bounds of a $95 \%$ range of the limit of agreement (LOA), as well as the zero value. The LOA and the Pearson Coefficient $(\mathrm{r})$ between measures obtained during test and retest were indicated in the top of the graphs. 


\section{Discussion}

This study adds Brazil to the list of countries where the MOHOST can be used - a country with a population of more than 208 million inhabitants (INSTITUTO..., 2010). The primary author of this study chose to introduce the MOHOST to Brazil because thus far, there were only three assessment instruments derived from the $\mathrm{MOHO}$ in the country, the Role Checklist, the Self-Assessment of Occupational Functioning Scale and the Occupational Performance History Interview - OPHI-I, and this fact pointed to limitations regarding the use of this model in Brazil (CRUZ, 2018). The author was already familiar with $\mathrm{MOHO}$ concepts and perceived that occupational therapists could aid patients in recovering lost occupational roles or to engage in new roles, by identifying contributing factors such as motivation, habituation, performance capacity, and environment (CRUZ; EMMEL, 2013).

Participation and performance are based on involvement in occupational roles (BONSAKSEN et al., 2015), and occupational therapists are encouraged to consider the MOHOST when developing clinical rationales in occupation-focused interventions because it evaluates occupational participation (KEPONEN; LAUNIAINEN, 2008). As such, it enables therapists to learn about individuals in the various dimensions of doing, which involve participation, performance, and skills (DE LAS HERAS DE PABLO; WEI-FAN; KIELHOFNER, 2017; KIELHOFNER, 2008; DE LAS HERAS DE PABLO; ABELENDA; PARKINSON, 2017).

The use of instruments originally written in a foreign language is common in non-English speaking countries. Nonetheless, because instruments are produced in other contexts, adaptation to the culture of the target country is essential (CASTRO; DAHLIN-IVANOFF; MÅRTENSSON, 2017). Cross-cultural adaptation studies are important for making the instruments more reliable in the target language. Simply translating an instrument to another language may distort the real meaning of items because concepts are influenced by the local culture (PERES et al., 2017). Residual barriers to the application of this instrument must be overcome, such as lack of understanding and the need for strategies to select and apply the model to benefit the greatest number of patients (WONG; FISHER, 2015), and further research regarding reliability and validity are recommended.

The stages described in this cross-cultural adaptation are valid and recommended in the current literature (CAMPOS et al., 2019; NOVELLI et al.,
2018; EPSTEIN; SANTO; GUILLEMIN, 2015; WILD et al., 2005). Changes were suggested in all the different stages, which is to be expected, considering that the objective of each stage is to revise the translated versions in order to attain a single version of the instrument. The literature reinforces the importance of this process, with theorists that cross-cultural adaptation has the potential to improve understanding of the translated version and make it possible to describe the same phenomenon in different cultures (BEATON et al., 2000; WILD et al., 2005; ORELLANO; JUTAI, 2013).

Semantics refers to the meaning of words, vocabulary and grammar (GUILLEMIN; BOMBARDIER; BEATON, 1993), and even when the initial translations and the back translation had been synthesised, disagreements concerning the semantic equivalence of words were observed in the Expert Committee's analysis. Qualitatively, some terms in question referred to the meanings used in the MOHOST, such as: 'throughout occupation'; 'valued occupations'; 'Appraisal of ability'. The discrepancies may have resulted from the fact that the participating therapists were not familiar with the instrument and were not given access to the "expanded criteria" in the MOHOST manual, which provide a detailed explanation of the items and the behaviours on which the ratings are based (PARKINSON; FORSYTH; KIELHOFNER, 2006). The manual had been translated, but the purpose of the study was to assess ease of understanding based on the assessment form alone.

Despite the occupational therapists not having access to the MOHOST manual, the assessment appeared to be easily understood by the occupational therapists who participated in the face validity confirmation process. This is important because knowledge and mastery of a standardized assessment instrument impacts on the rest of the therapeutic process. It enables the collection of clinical data, establishing therapeutic goals, directing interventions, and making evident any clinical changes experienced by the population under study so that, ultimately, occupational therapists can guide interventions and expand research in the field (CHAVES et al., 2010).

Good understanding of the instrument, even by those who are not familiar with the $\mathrm{MOHO}$, may be explained by the fact that the original MOHOST adopted simple and accessible language, for instance, instead of using 'Volition', 'Motivation for Occupation' was used and instead of 'Habituation', 'Pattern of Occupation' was used. Simple language makes items clear and facilitates the use of an instrument (PARKINSON et al., 2011, 2017; PARKINSON; 
FORSYTH; KIELHOFNER, 2006). On the other hand, this study discovered a relationship between years of professional practice and familiarity with the MOHO and this show the importance of understanding the Model and its theory when applying its concepts in practice. Correlation between practical experience and familiarity with the $\mathrm{MOHO}$ can also be explained because $\mathrm{MOHO}$ is a Conceptual Model of Practice which stems from practice and has been revised based on feedback which has originated in practice (KIELHOFNER, 2008; KIELHOFNER, 2009).

This study's analysis of the test-retest results shows that the MOHOST's general scores and those concerning its six factors presented good reproducibility, as the scores obtained by all the individuals were within a 95\% confidence interval, confirming the reliability of the MOHOST Brazil.

An interesting aspect is that the general scores obtained on the test were slightly higher than those obtained on the retest, which was not the case when the same analysis was performed for the factors analysed in isolation. This can be partly explained by the fact that the MOHOST has six factors, and studies employing factor analysis indicate that it is more appropriate to analyse its six dimensions than perform a uni-dimensional analysis (KIELHOFNER et al., 2009).

A potential explanation for the results regarding the general scores is that the therapists may have acquired a better understanding of how to apply the instrument and deepened their clinical rationale of the occupational participation of their clients for the second time they applied the instrument. Another explanation is that the variables introduced by the observers may be generated by multiple sources of information that are gathered to produce an answer, while it may difficult to separate them from those produced by the instrument itself (LOURENÇO; VERAS; RIBEIRO, 2008).

\section{Conclusion}

The cross-cultural adaptation of the MOHOST Brazil has been completed and is intended to aid occupational therapists in contributing to the organization of occupational therapy services, to document the progression of interventions, to apply evidence-based practice, and compare data from studies developed with the MOHOST worldwide.

Data concerning face validity indicate that occupational therapists can easily comprehend its items. Now, further research is needed to address the limitations of this study. These include having a small convenience sample which does not allow for the generalization of results. Our data about test-retest support evidence reported in the literature that the MOHOST presents good psychometric properties of reliability. Additionally, further studies are needed to examine this instrument's psychometric properties, checking for different types of validity. Cross-cultural adaptation studies are important to making the use of instruments more reliable in the target language, and the authors believe that making the MOHOST available in Brazil will contribute to the use of the $\mathrm{MOHO}$ in research and clinical practice because it allows occupational participation to be measured, and occupational therapists need to have valid and reliable measures to assess occupational participation and guide their practice and research (MACIVER et al., 2016).

\section{References}

ALEXANDRE, N. M. C.; COLUCI, M. Z. Validade de conteúdo nos processos de construção e adaptação de instrumentos de medida. Ciência \& Saúde Coletiva, Rio de Janeiro, v. 16, n. 7, p. 3061-3068, 2011. http://dx.doi. org/10.1590/S1413-81232011000800006.

BEATON, D. E. et al. Guidelines for the process of cross-cultural adaptation of self-report measures. Spine, Hagerstown, v. 25, n. 24, p. 3186-3191, 2000. http:// dx.doi.org/10.1097/00007632-200012150-00014. PMid:11124735.

BONSAKSEN, T. et al. Does the role checklist measure occupational participation? The Open Journal of Occupational Therapy, Michigan, v. 3, n. 3, p. 1-12, 2015. http://dx.doi. org/10.15453/2168-6408.1175.

CAMPOS, L. C. B. et al. Adaptação transcultural e validade face do Wheelchair Skills Test Questionnaire (versão 4.3) para cuidadores. Cadernos Brasileiros de Terapia Ocupacional, São Carlos, v. 27, n. 1, p. 17-26, 2019. http://dx.doi. org/10.4322/2526-8910.ctoAO1594.

CASTRO, D.; DAHLIN-IVANOFF, S.; MÅRTENSSON, L. Test-retest reliability evaluation of the Escala de Conciencia Cultural para Estudiantes de Terapia Ocupacional en América Latina (ECCETO). Cadernos de Terapia Ocupacional da UFSCar, São Carlos, v. 25, n. 1, p. 3-20, 2017. http:// dx.doi.org/10.4322/0104-4931.ctoAO0919.

CHAVES, G. F. S. et al. Evaluation scales for occupational therapy in Brazil. Revista de Terapia Ocupacional da Universidade de São Paulo, São Paulo, v. 21, n. 3, p. 240246, 2010. http://dx.doi.org/10.11606/issn.2238-6149. v21i3p240-246.

COSTER, W. J.; MANCINI, M. C. Recommendations for translation and cross-cultural adaptation of instruments for occupational therapy research and practice. Revista de Terapia Ocupacional da Universidade de São Paulo, São Paulo, 
v. 26, n. 1, p. 50-57, 2015. http://dx.doi.org/10.11606/ issn.2238-6149.v26i1p50-57.

CRUZ, D. M. C. Models of practice in occupational therapy and possibilities for clinical practice and research in Brazil. Revisbrato, João Pessoa, v. 2, n. 3, p. 504-517, 2018.

CRUZ, D. M. C.; EMMEL, M. L. G. Associations among occupational roles, independence, assistive technology, and purchasing power of individuals with physical disabilities. Revista Latino-Americana de Enfermagem, Ribeirão Preto, v. 21, n. 2, p. 484-491, 2013. http://dx.doi.org/10.1590/ S0104-11692013000200003. PMid:23797540.

DE LAS HERAS DE PABLO, C. G.; ABELENDA, J.; PARKINSON, S. MOHO: based program development. In: TAYLOR, R. Kielhofner's model of human occupation. Philadelphia: Wolters Kluwer, 2017. p. 397-417.

DE LAS HERAS DE PABLO, C. G.; WEI-FAN, C.; KIELHOFNER, G. Dimensions of doing. In: TAYLOR, R. Kielhofner's model of human occupation. Philadelphia: Wolters Kluwer, 2017. p. 107-122.

EPSTEIN, J.; SANTO, R. M.; GUILLEMIN, F. A review of guidelines for cross-cultural adaptation of questionnaires could not bring out a consensus. Journal of Clinical Epidemiology, London, v. 68, n. 4, p. 435-441, 2015. http://dx.doi.org/10.1016/j.jclinepi.2014.11.021. PMid:25698408.

FORSYTH, K. et al. The measurement properties of the model of human occupation screening tool and implications for practice. New Zealand Journal of Occupational Therapy, Auckland, v. 58, n. 2, p. 5-13, 2011.

GRAVETTER, F. J.; FORZANO, L. A. B. Research methods for the behavioral sciences. Belmont: Wadsworth, 2012.

GUILLEMIN, F.; BOMBARDIER, C.; BEATON, D. Cross-cultural adaptation of health-related quality of life measures: literature review and proposed guidelines. Journal of Clinical Epidemiology, London, v. 46, n. 12, p. 1417-1432, 1993. http://dx.doi.org/10.1016/08954356(93)90142-N. PMid:8263569.

HAWES, D.; HOULDER, D. Reflections on using the Model of Human Occupation Screening Tool in a joint learning disability team. British Journal of Occupational Therapy, London, v. 73, n. 11, p. 564-567, 2010. http:// dx.doi.org/10.4276/030802210X12892992239431.

HOLDEN, R. B. Face validity. In: WEINER, I. B.; CRAIGHEAD, W. E. The Corsini Encyclopedia of Psychology. New Jersey: Wiley, 2010. p. 637-638. http://dx.doi. org/10.1002/9780470479216.corpsy0341.

INSTITUTO BRASILEIRO DE GEOGRAFIA E ESTATÍSTICA - IBGE. Censo demográfico: resultados preliminares da amostra 2010. Rio de Janeiro, 2010. Available from: <http://www.ibge.gov.br/home/estatistica/ populacao/censo2010/resultados_preliminaresamostra/ default_resultados_preliminares_amostra.shtm >. Access on: 20 Nov. 2018.
KEPONEN, R.; LAUNIAINEN, H. Using the model of human occupation to nurture an occupational focus in the clinical reasoning of experienced therapists. Occupational Therapy in Health Care, Oxfordshire, v. 22, n. 2-3, p. 95-104, 2008. http://dx.doi.org/10.1080/07380570801989549. PMid:23941376.

KIELHOFNER, G. Model of human occupation: theory and application. Baltimore: Lippincott Williams \& Wilkins, 2008.

KIELHOFNER, G. Conceptual foundations of occupational therapy. Philadelphia: Davies Company, 2009.

KIELHOFNER, G. et al. A factor analytic study of the model of human occupation screening tool of hypothesized variables. Occupational Therapy in Mental Health, Oxfordshire, v. 25, n. 2, p. 127-137, 2009. http:// dx.doi.org/10.1080/01642120902856846.

KIELHOFNER, G. et al. Psychometric study of the Model of Human Occupation Screening Tool (MOHOST). Hong Kong Journal of Occupational Therapy, Hong Kong, v. 20, n. 2, p. 63-70, 2010. http://dx.doi.org/10.1016/ S1569-18611170005-5.

KRAMER, J. et al. Utility of the Model of Human Occupation Screening Tool for detecting client change. Occupational Therapy in Mental Health, Oxfordshire, v. 25, n. 2, p. 181 191, 2009. http://dx.doi.org/10.1080/01642120902859261.

LEE, S. W. et al. Impact of using the Model of Human Occupation: a survey of occupational therapy mental health practitioners' perceptions. Scandinavian Journal of Occupational Therapy, Stockholm, v. 19, n. 5, p. 450-456, 2012. http://dx.doi.org/10.3109/11038128.2011.64555 3. PMid:22214401.

LOURENÇO, R. A.; VERAS, R. P.; RIBEIRO, P. C. C. Confiabilidade teste-reteste do Mini-Exame do Estado Mental em uma populaçáo idosa assistida em uma unidade ambulatorial de saúde. Revista Brasileira de Geriatria e Gerontologia, Rio de Janeiro, v. 11, n. 1, p. 7-16, 2008. http://dx.doi.org/10.1590/1809-9823.2008.11012.

MACIVER, D. et al. A Rasch analysis of the model of human occupation screening tool single observation form (MOHOST-SOF) in mental health. British Journal of Occupational Therapy, London, v. 79, n. 1, p. 49-56, 2016. http://dx.doi.org/10.1177/0308022615591173.

MODEL OF HUMAN OCCUPATION. Model of human occupation: theory and application. 2016. Available from: <https://www.moho.uic.edu/>. Access on: 13 Feb. 2016.

MORLEY, M.; BIRKEN, M. Foreword. In: PARKINSON, S. Recovery through activity: increasing participation in everyday life. London: Routledge, 2014. p. vi-vii.

NOTOH, H. et al. Examining the psychometric properties of the model of human occupation screening tool-japanese version. Hong Kong Journal of Occupational Therapy, Hong Kong, v. 23, n. 1, p. 26-31, 2013. http://dx.doi. org/10.1016/j.hkjot.2013.06.001. 
NOVELLI, M. M. P. C. et al. Cross-cultural adaptation of the Tailored Activity Program (TAP) for Brazilian Portuguese. Cadernos Brasileiros de Terapia Ocupacional, São Carlos, v. 26, n. 1, p. 5-15, 2018. http://dx.doi. org/10.4322/2526-8910.ctoAO0851.

ORELLANO, E. M.; JUTAI, J. W. Cross-cultural adaptation of the psychosocial impact of assistive device scale (PIADS) for Puerto Rican assistive technology users. Assistive Technology, Oxfordshire, v. 25, n. 4, p. 194-203, 2013. http://dx.doi.org/10.1080/10400435.2012.7612 92. PMid:24620702.

PARKINSON, S. et al. Enhancing professional reasoning through the use of evidence-based assessments, robust case formulations and measurable goals. British Journal of Occupational Therapy, London, v. 74, n. 3, p. 148-152, 2011. http://dx.doi.org/10.4276/030802211X12996065859364.

PARKINSON, S. et al. Assessments combining methods of information gathering. In: TAYLOR, R. Kielhofner's model of human occupation. Philadelphia: Wolters Kluwer, 2017. p. 291-310.

PARKINSON, S.; FORSYTH, K.; KIELHOFNER, G. User's manual for the Model of Human Occupation Screening Tool (MOHOST) version 2.0. Chicago: University of Illinois, 2006.
PAULISSO, D. C. et al. Functional mobility assessment is reliable and correlated with satisfaction, independence and skills. Assistive Technology, Oxfordshire, p. 1-7, 2019. In press. http://dx.doi.org/10.1080/10400435.2019.162 9125. PMid:31207193.

PERES, D. et al. Cross-cultural adaptation of the Chedoke Arm and Hand Activity Inventory (CAHAI). Cadernos Brasileiros de Terapia Ocupacional, Sáo Carlos, v. 25, n. 3, p. 595-605, 2017. http://dx.doi.org/10.4322/25268910.ctoAO0869.

TAYLOR, R. R. Preface and editorial introduction to the fith edition. In: TAYLOR, R. Kielhofner's model of human occupation. Philadelphia: Wolters Kluwer, 2017. p. vii-ix.

WILD, D. et al. Principles of Good Practice for the Translation and Cultural Adaptation Process for PatientReported Outcomes (PRO) Measures: Report of the ISPOR Task Force for Translation and Cultural Adaptation. Value in Health, London, v. 8, n. 2, p. 94-104, 2005. http://dx.doi.org/10.1111/j.1524-4733.2005.04054.x. PMid:15804318.

WONG, S. R.; FISHER, G. Comparing and using occupation-focused models. Occupational Therapy in Health Care, Oxfordshire, v. 29, n. 3, p. 297-315, 2015. http://dx.doi.org/10.3109/07380577.2015.1010130. PMid:25993054

\section{Author's Contributions}

Daniel Marinho Cezar da Cruz study design, data collection, data analysis, text writing, and final review. Sue Parkinson reviewed the back translation version and writing reviews. Daniela da Silva Rodrigues writing reviews and references. Débora Couto de Melo Carrijo research data collection and text writing. Jacqueline Denubila Costa research data collection and text writing. Emerson Fachin-Martins statistical analysis and final review. Luzia Iara Pfeifer supervised the research and reviewed the manuscript. All authors approved the final version of the text.

\section{Notes}

${ }^{1}$ Research approved in 2016 by the Ethics Committee for Research with Human Beings from the Federal University of Sao Carlos, Sao Paulo, Brazil (protocol number CAAE 68946717.7.0000.5504). 